\title{
MODIFICATION OF RHEOLOGICAL PROPERTIES OF BIOFUELS FROM SOYBEAN OIL
}

\author{
Zbigniew KOBUS, Kamil WILCZYŃSKI, Rafał NADULSKI, Tomasz GUZ \\ University of Life Sciences in Lublin, POLAND \\ E-mail of corresponding author: zbigniew.kobus@up.lublin.pl
}

Keywords: biofuels, viscosity, soybean oil, sustainable agriculture

\begin{abstract}
In this paper, the influence of fuel additives on rheological properties of crude soybean oil was presented. The tests were performed for low shear rates $\left(1.2-12.4 \mathrm{~s}^{-1}\right)$ at a temperature range of 5 to $30^{\circ} \mathrm{C}$. The fuel mixtures were prepared in a proportion of $80 \%$ soybean oil to $20 \%$ diesel or $20 \%$ depressor. Flow curves, viscosity curves, flow index and consistency coefficients were determined. Diluting soybean oil with fuel additives caused a significant decrease in viscosity and changed the rheological character of the obtained oil biofuels. Diesel oil has reduced the viscosity of soybean oil more visibly than the depressor. Modification of soybean oil by fuel additives significantly reduces the viscosity of the obtained fuel blends and can contribute to the development of sustainable agriculture.
\end{abstract}

\section{INTRODUCTION}

Vegetable oils are renewable and clean energy source and can be a substitute to diesel fuel (Shay 1993; Altin et al., 2001) The vegetable oils can be produced from numerous oil seed crops and have high energy contents (Franco and Nguyen 2011). Biofuels from vegetable oils are biodegradable and nontoxic, have low emission profiles and so are environmentally beneficial (Ma and Hanna 1999).

The added advantage of biofuels is that they can be used for their own use by small farms (Kobus at el., 2015), what is important for the development of sustainable agriculture.

A major obstacle deterring their use in the direct-injection diesel engine is their high viscosities (Schwab et al., 1987; Mustafa and Gerpen 1999).

The viscosity of the fuel is of great importance for the correct exploitation of the engine and fuel system. It determines the quality of spraying in the combustion chamber, the flow resistance of the fueled wires and filters, and affects the lubrication of the injection pumps (Baczewski and Kołduński 2005, Jakóbiec et al., 2011). One of the ways to improve selected properties of crude vegetable oils is to use common fuel additives (Shah and Ganesh 2016). These include conventional fuels (diesel) or cold starters (depressors). The aim of the study was to investigate the effect of different compounds on the rheological properties of soybean oil.

\section{MATERIAL AND METHODS}

The raw soybean oil obtained after screw pressing was used in the study. Diesel and depressor were used to modify the oil properties. In both cases, the fuel blend was prepared in the proportion of $80 \%$ soybean oil and $20 \%$ fuel additive.

Rheological properties were measured using Brookfield viscometer (Brookfield Engineering Laboratories: model LVDV-II + PRO). A sample of $16 \mathrm{ml}$ of oil was used in ULA-baker for all experiments. The temperature of sample was changed from 5 to $30^{\circ} \mathrm{C}$ and kept at constant value using water bath (Brookfield TC-502P). The computer software (Rheolac 3.1) was applied to control viscometer and data acquisition. All experiments were carried out in three replications. 


\section{RESULTS}

In Figure 1 the viscosity curves of soybean oil, diesel and depressor at temperature of $30^{\circ} \mathrm{C}$ were shown.

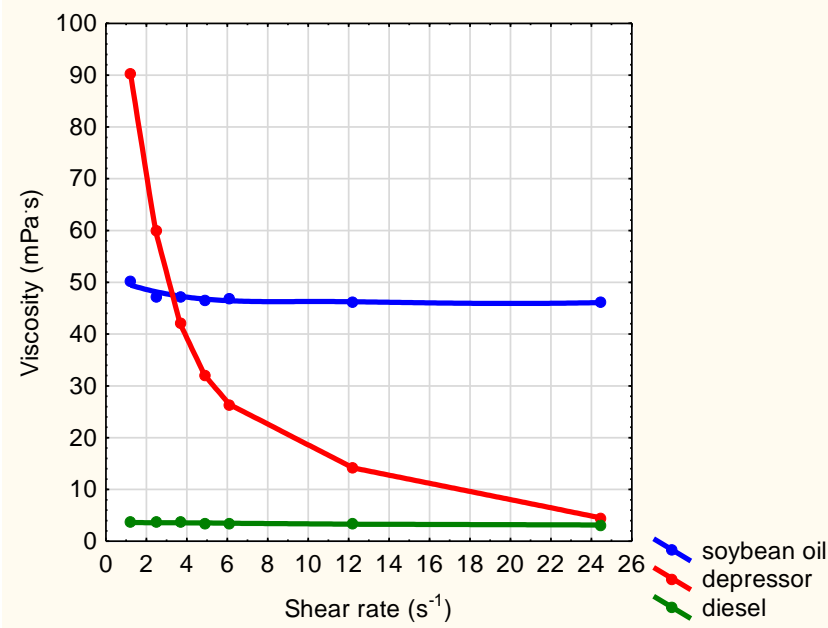

Fig. 1. The viscosity curves of soybean oil, diesel and depressor at temperature of $30^{\circ} \mathrm{C}$

The tested liquids significantly differed in both viscosity values and rheological characteristics. Diesel has been characterized by Newtonian fluid behavior and low dynamic viscosity. Raw soybean oil exhibited the characteristics of a Newtonian liquid and had about 18 times larger the apparent viscosity. The depressor exhibited strong pseudoplastic properties and had the highest apparent viscosity at the lowest shear rate.

In Figure 2 the flow curves of soybean oil with addition of diesel and depressor at different temperatures were shown.

a

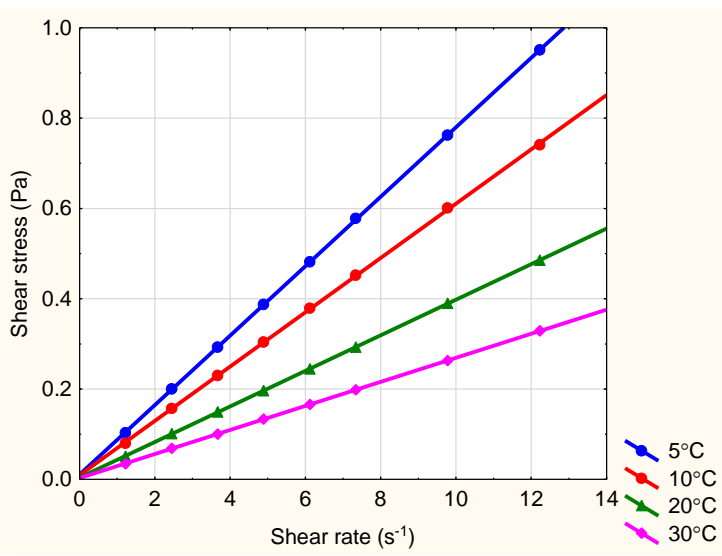

b

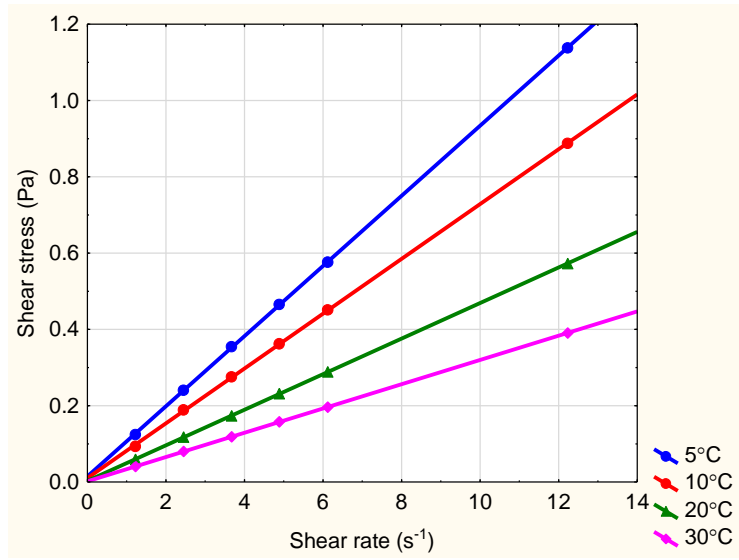

Fig. 2. Flow curves of soybean oil at different temperatures with addition of: a) diesel, b) depressor

In Figure 3 the viscosity curves of soybean oil with addition of diesel and depressor at different temperatures were shown. 
a

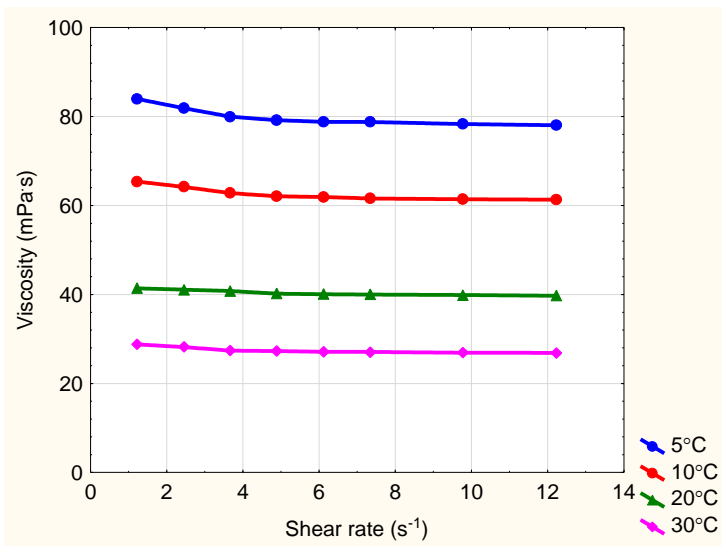

b

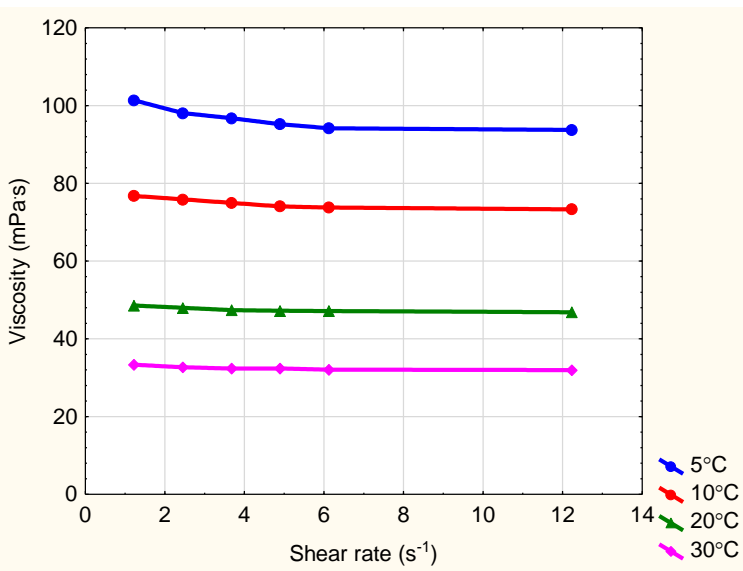

Fig. 3. Viscosity curves of soybean oil at different temperatures with addition of: a) diesel, b) depressor

To verify the rheological character of the obtained fuel blends, the flow index and the consistency coefficient were calculated. These values are summarized in Table 1.

Table 1. Rheological properties of power law model for modified soybean oil

\begin{tabular}{|c|c|c|c|c|}
\hline \multirow{2}{*}{$\begin{array}{c}\text { Temperature } \\
\left({ }^{\circ} \mathbf{C}\right)\end{array}$} & \multicolumn{2}{|c|}{ Soybean oil + diesel } & \multicolumn{2}{c|}{ Soybean oil + depressor } \\
\cline { 2 - 5 } & $\begin{array}{c}\text { Consistency } \\
\text { coefficient }\left(\mathrm{Pa} \cdot \mathrm{s}^{\mathrm{n}}\right)\end{array}$ & $\begin{array}{c}\text { Flow behaviour } \\
\text { index }(-)\end{array}$ & $\begin{array}{c}\text { Consistency } \\
\text { coefficient }\left(\mathrm{Pa} \cdot \mathrm{s}^{\mathrm{n}}\right)\end{array}$ & $\begin{array}{c}\text { Flow behaviour } \\
\text { index }(-)\end{array}$ \\
\hline 5 & 0.085 & 0.95 & 0.102 & 0.95 \\
\hline 10 & 0.066 & 0.98 & 0.078 & 0.97 \\
\hline 20 & 0.042 & 0.99 & 0.049 & 0.99 \\
\hline 30 & 0.029 & 0.99 & 0.033 & 0.99 \\
\hline
\end{tabular}

Flow indexes for temperatures ranging from 10 to $30^{\circ} \mathrm{C}$ were close to unity, what confirms a Newtonian behaviour of soybean oil mixture with fuel additives. Only in the case of the $5^{\circ} \mathrm{C}$ temperature, the flow index of the fuel blends was slightly different from the unity, what indicates on the pseudoplastic nature of the tested liquid.

\section{CONCLUSIONS}

Rheological analysis of soybean oil and its mixtures with diesel and depressor was performed. The tests were conducted at a temperature range from 5 to $30^{\circ} \mathrm{C}$. The soybean oil showed non-Newtonian, pseudoplastic behaviour at the range of low shear rates $(1.2$ $-12.4 \mathrm{~s}^{-1}$ ). The addition of diesel fuel resulted in a significant decrease in the viscosity and for the temperature range of 10 to $30^{\circ} \mathrm{C}$ and the change of rheological character of oil from non-Newtonian to Newtonian. In the case of $5^{\circ} \mathrm{C}$ temperature, the fuel mixture retained its pseudoplastic character. A similar effect was obtained when the depressor was added to soybean oil. However, diesel fuel was a more effective agent than the depressor in viscosity reduction of mixtures derived from soybean oil. The applied fuel additives significantly lowered the viscosity of soybean oil fuel blends. The proposed biofuels could significantly reduce the environmental pollution and contribute to the development of sustainable agriculture. 


\section{REFERENCES}

Altin, R, Cetinkaya, S, Yucesu, HS. (2001). The potential of using vegetable oil fuels as fuel for diesel engines. Energy Conversion and Management, 42 (5), 529-38.

Baczewski, K., Kołduński, T., (2005). Paliwa do silników o zapłonie iskrowym, WKiŁ, Warszawa.

Franco, Z., Nguyen, Q.D., (2011). Flow properties of vegetable oil-diesel fuel blends. Fuel, 90 (2), 838843.

Jakóbiec, J., Bocheńska, A., Ambroziak, A., (2011). Modyfikacja właściwości fizyko-chemicznych i użytkowych paliwa rzepakowego. Inżynieria Rolnicza, 15 (4), 85-92.

Kobus, Z., Mazur, J., Nadulski, R., Guz, T., Rydzak, L., Zawiślak, K., (2015). Modification of rheological properties of vegetables oil. Przemyst Chemiczny, 10 (94), 1728-1731.

Ma, F.R., Hanna, M.A., (1999). Biodiesel production: a review. Bioresource Technology, 70 (1), 1-15.

Mustafa, E.T., Van Gerpen, J.H., (1999). The kinematic viscosity of biodiesel and its blends with diesel fuel. Journal of the American Oil Chemists' Society, 76 (12), 1511-1513.

Shah, P.R. Ganesh, A. (2016). A comparative study on influence of fuel additives with edible and nonedible vegetable oil based on fuel characterization and engine characteristics of diesel engine. Applied Thermal Engineering, 102 (5), 800-812.

Schwab, A.W, Bagby, M.O, Freedman, B. (1987). Preparation and properties of diesel fuels from vegetable oils. Fuel, 66 (10), 1372-1378.

Shay, E.G. (1993). Diesel fuel from vegetable oils. Status and opportunities. Biomass and Bioenergy, 4 (4), 227-242. 